\title{
Novel Mutation of Exon 5 Prolactin Gene in IPB-D1 Chicken
}

\author{
Rohmah L ${ }^{1,2}$, Darwati $\mathrm{S}^{2}$, Ulupi $\mathrm{N}^{2}$, Khaerunnisa $\mathrm{I}^{3}$, Sumantri $\mathrm{C}^{2}$ \\ ${ }^{1}$ Graduate School. Department of Animal Production and Technology, IPB University, Bogor 16680 \\ ${ }^{2}$ Department of Animal Production and Technology, Faculty of Animal Science, IPB University, Bogor 16680 \\ ${ }^{3}$ Indonesian Institute of Sciences, Sasana Widya Sarwono (SWS), Jl. Jend. Gatot Subroto 10, Jakarta 12710 \\ E-mail: lailatulrohmahh@gmail.com
}

(received 19-06-2020; revised 29-09-2020; accepted 15-10-2020)

\begin{abstract}
ABSTRAK
Rohmah L, Darwati S, Ulupi N, Khaerunnisa I, Sumantri C. 2020. Mutasi baru gen prolaktin ekson 5 pada ayam IPB-D1. JITV 25(4): 173-181.DOI: http://dx.doi.org/10.14334/jitv.v25i4.2525

Gen prolaktin (PRL) merupakan salah satu gen yang mengontrol sifat mengeram dan produksi telur Pada ayam petelur. Sifat mengeram akan menurunkan produksi telur dan mengganggu sistem reproduksi pada ayam lokal. Tujuan dari penelitian ini yaitu mengidentifikasi keragaman gen prolaktin pada ayam IPB-D1 dengan menggunakan metode direct sequencing. Analisis keragaman pada gen prolaktin ekson 5 dilakukan pada 46 sampel DNA ayam IPB-D1 yang merupakan koleksi Divisi Genetika dan Pemuliaan Ternak, Fakultas Peternakan IPB. Sekuens DNA sebagai acuan untuk merancang primer ekson 5 didapatkan dari National Center for Biotechnology Information (NCBI) dengan kode akses GenBank AF288765.2. Ekstraksi DNA dilakukan dengan menggunakan teknik phenol-chloroform. Amplifikasi DNA menghasilkan produk PCR dengan ukuran $557 \mathrm{pb}$. Pada penelitian ini dihitung frekuensi genotipe, frekuensi alel, dan nilai heterozigositas serta keseimbangan Hardy-Weinberg. Hasil penelitian menemukan 5 SNP pada ekson 5, yaitu g.7823A $>$ G, g.7835A $>$ G, g.7886T $>$ A, g.8052T $>$ C, dan g.8069T $>$ C. Seluruh SNPs bersifat polimorfik dan berada dalam keseimbangan Hardy-Weinberg kecuali g.8052T $>$ C. Mutasi basa g.7823A $>\mathrm{G}$, g.7835A > G, g.8052T >C merupakan mutasi synonymous yang tidak mengubah asam amino, sedangkan mutasi basa g.7886T $>\mathrm{A}$ dan g.8069T $>$ C merupakan SNP non-synonymous yang mengubah asam amino sehingga dapat dijadikan sebagai kandidat marker assisted selection sifat produksi telur pada ayam IPB-D1.
\end{abstract}

Kata Kunci: Ayam IPB-D1, Gen Prolaktin, Mutasi, SNP

\begin{abstract}
Rohmah L, Darwati S, Ulupi N, Khaerunnisa I, Sumantri C. 2020. Novel mutation of exon 5 prolactin gene in IPB-D1 chicken. JITV 25(4): 173-189. DOI: http://dx.doi.org/10.14334/jitv.v25i4.2525

The prolactin gene (PRL) is a gene that controls the incubation and egg production in laying chickens. The nature of incubation will reduce egg production and disrupt the reproductive system in local chickens. The purpose of this study was to identify the polymorphism of prolactin genes in IPB-D1 chickens using the direct sequencing method. The polymorphism of the exon 5 prolactin gene was carried out on 46 samples of IPB-D1 chicken DNA which was a collection of the Division of Animal Genetics and Breeding, Faculty of Animal Science IPB. DNA sequences as a reference for designing exon 5 primers were obtained from the National Center for Biotechnology Information (NCBI) with the GenBank access code: AF288765.2. DNA extraction was carried out using the phenol-chloroform technique. DNA amplification resulted in a PCR product with a size of $557 \mathrm{bp}$. In this study, the genotype frequency, allele frequency, heterozygosity value and Hardy-Weinberg equilibrium were calculated. The results of the study found 5 SNPs in exon 5, namely g.7823A $>$ G, g.7835A $>$ G, g.7886T $>$ A, g.8052T $>$ C, and g.8069T $>$ C. All SNPs are polymorphic and in Hardy-Weinberg equilibrium except g.8052T $>$ C. The g.7823A $>$ G, g.7835A $>$ G, g.8052T $>$ C SNPs are synonymous mutations that do not change amino acids, while the g.7886T $>$ A and g.8069T $>C$ SNPs are non-synonymous that change amino acids. Both g.7886T $>$ A and g.8069T $>$ C SNPs are potential as a marker assisted selection for the characteristics of egg production in IPB-D1 chickens.
\end{abstract}

Key Words: IPB-D1 Chicken, Mutation, Prolactin Gene, SNP

\section{INTRODUCTION}

In 2019, the native chicken population in Indonesia was approximately $8.37 \%$ of the national chicken population (DJPKH 2019). This contributed $6.01 \%$ of the total national meat production in 2018 which decreased compared to those in 2017 (DJPKH 2019).
The low productivity of native Indonesian chicken eggs is one of the challenges of the native Indonesian chicken industry. Sinurat et al. (1992) in: Hidayat \& Asmarasari (2015) reported that the egg production of native chicken that is extensively reared is up to 30.20 eggs per chicken per year. Meanwhile, with an intensive maintenance system, the egg production of native 
chicken eggs reaches 80.30 eggs per chicken per year (Sinurat et al. 1992). One of the solutions to increase the productivity of local chickens is the invention of a novel crossbreed chicken, namely IPB-D1 (Ministry of Agriculture Reg No. 693/KPTS/PK.230/M/9/2019). IPB-D1 chicken is a result of crossbreeding between F1

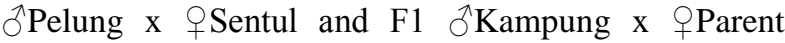
Stock Cobb. The superiority of this chicken is its fast growth, which reaches $1.18 \pm 0.2 \mathrm{~kg}$ (male) or $1.04 \pm$ $0.12 \mathrm{~kg}$ (female) slaughter weight at the age of 10-12 weeks. In addition, this chicken also resistant to New Castle disease (Sumantri \& Darwati 2017).

The IPB-D1 composite chickens also showed the superiority of reproduction and egg production. Cholifah (2018) reported that crossbreeding between pelung, sentul, Kampung, and broiler chickens produced higher fertility, higher hatchability, and lower mortality than Kampung chicken. In addition, the crossbreeding between Kampung chicken with broilers has a low incubation capacity that is able to produce a higher egg production. The production and reproduction of the IPB-D1 chicken in the $3^{\text {rd }}$ generation, in this case, is explained by Sumantri \& Darwati (2017). It is mentioned that the age of first laying eggs is 24 weeks with bodyweight of $1.80 \pm 0.23 \mathrm{~kg}$. Meanwhile, egg production of the chicken is $45.20 \%$ with the egg weight which is $33.50 \pm 0.97$ grams. Furthermore, the egg fertility of IPB-D1 chicken is $84.25 \%$ with $64.70 \%$ of hatchability (Sumantri \& Darwati 2017). In further research, Habiburahman et al. (2020) mentioned that the egg production of this chicken increased to $49.22 \%$ in the $7^{\text {th }}$ generation. The increase in egg production of IPB D-1 G7 chickens was due to the genetic percentage of broilers as much as $25 \%$. The $25 \%$ genetic contribution of purebred chickens has led to an increase in egg production of IPB D-1 chicken $7^{\text {th }}$ generation compared to local chickens in general.

To overcome the low production of native chicken eggs among other things, influenced by the nature of the incubation, it can be done by reducing or eliminating the broody nature of the chicken. Molecular selection can be done quickly and as early as possible through the marker assisted selection of natural brooding. The prolactin gene (PRL) is a gene that controls the incubation and egg production in laying chickens. Prolactin is a single chain polypeptide hormone that belongs to a family of growth hormone genes and is generally synthesized in the anterior pituitary in all vertebrate animals (Sharp et al. 1979). In aves, it has been reported that prolactin has many important roles in the regulation of physiological processes, including egg production, stimulating and maintaining the nature of the incubation, osmoregulation, immune-modulation, function and development of gonad cells (Plant \& Zeleznik 2014). Sherwood et al. (2005) mentioned that prolactin is a gene that controls the nature of brooding because prolactin is an important part of the functioning of neuroendocrine which stimulates the occurrence of incubation. This incubation event is caused by the prolactin promoter functioning to activate the initial transcription of the prolactin gene expression. Mutations in the prolactin promoter are reported to affect the activity of the prolactin gene in the incubation process (Sartika 2005). In this case, the prolactin gene (PRL) has a major role in the nature of the incubation and egg production in chickens. Therefore prolactin gene can be used as genetic markers in Indonesian local chicken selection programs, especially in IPB-D1 chickens. This study aims to identify the polymorphism of prolactin genes (PRL) in IPB-D1 chickens.

\section{MATERIALS AND METHODS}

\section{Animals}

All procedures performed in this study were approved by the Animal Care and Use Committee (ACUC) of IPB University (ACUC No: 163-2019 IPB). A number of 46 IPB-D1 chickens (24 weeks-old, hen) were collected from Genetics and Animal Breeding Division, Faculty of Animal Science, IPB. All chickens were kept under uniform conditions with a uniform feed of protein and energy balance. Feed and water were given ad libitum. Blood samples were taken from the pectoralis vein in the wing area. From this process, a total of 1.0-1.5 ml samples were taken using a syringe. Blood is put into a tube containing K3-EDTA (ethylenediamine tetraacetic) anticoagulant and then stored in a refrigerator at $4{ }^{\circ} \mathrm{C}$ until it is ready for DNA extraction.

\section{Primer designing}

The primer sequences were designed using the Primer3 and BLAST Primer applications from NCBI to obtain the primer target according to Ye et al. (2012). It also used the Primer Stats application for primer compatibility test. The length of the PCR product was $557 \mathrm{bp}$ and it is located in exon 5. Sequential data for the primer design were obtained from the National Center for Biotechnology Information (NCBI) with the GenBank access code: AF288765.2. The primer sequence used in this was the author's design with the following primers. The forward primer sequence was (F): 5'-TGGAGGAGGCCAAAAAGAGATG-3' and reverse primer sequence was (R): 5'GCAGCCCACAGGTACTTAGC-3'.

\section{DNA isolation}

Genomic DNA was extracted by using Phenolchloroform technique (Sambrook \& Russell 2001) and 
modified by adding cells buffer lysis $(250 \mu 11 \mathrm{x}$ STE, $40 \mu \mathrm{l} \mathrm{SDS}$, and $10 \mu \mathrm{l}$ proteinase-K). The DNA was purified by adding $40 \mu \mathrm{l} 5 \mathrm{M} \mathrm{NaCl}, 400 \mu \mathrm{l}$ phenol, and $400 \mu \mathrm{l}$ CIAA (Chloroform Iso Amyl Alcohol) and precipitated by using $40 \mu \mathrm{l} 5 \mathrm{M} \mathrm{NaCl}$ and $800 \mu \mathrm{l}$ ethanol absolute. The precipitation was washed once by adding $800 \mu \mathrm{l}$ of $70 \%$ ethanol and centrifuged with a speed of $12.000 \mathrm{rpm}$ for $5 \mathrm{~min}$. The ethanol was discarded and evaporated, then the precipitated DNA was dissolved in $100 \mu 1$ of $80 \%$ TE (Elution buffer).

\section{DNA amplification}

The amplification of PRL gene fragments was done by PCR machine. The DNA sample to be amplified was transferred into a $0.2 \mathrm{ml}$ tube with a sample volume of $0.5 \mu 1$. After the sample was added the $14 \mu 1$ premix containing $0.4 \mu 1$ primers, $12.5 \mu 1$ Green Master mix, and $11.1 \mu 1$ Nuclease Free Water. Then the sample was homogenized and put into the ESCO Swift Maxi Thermal Cycler machine. The PCR technique was carried out through 3 stages. The first stage was the cycle of the temperature predenaturation process of $95^{\circ} \mathrm{C}$ for 5 minutes and the second stage, it was carried out 35 cycles consisting of denaturation $\left(95^{\circ} \mathrm{C}\right)$ for 10 seconds, annealing $\left(57^{\circ} \mathrm{C}\right)$ for $20 \mathrm{sec}$, and extension $\left(72^{\circ} \mathrm{C}\right)$ for 30 seconds. Meanwhile, the third stage was in the form of a final extension $\left(72^{\circ} \mathrm{C}\right)$.

\section{Direct sequencing and genotyping}

Direct sequencing was carried out from two directions, forward and reverse. Sequence products were obtained by using services from 1st Base Selangor, Malaysia. The sample sequencing results were then verified through alignment by multiple alignment ClustalW in MEGA-X (Kumar et al. 2018). The alignment of IPB-D1 chicken samples was carried out using BioEdit programs to identify the polymorphism in this study (Alzohairy 2011). IPB-D1 chicken sequences were compared with GenBank from the National Center for Biotechnology Information (NCBI) with access code of the GenBank AF288765.2. The sequencing chromatogram results are scanned using FinchTV programs to identify heterozygous of the polymorphic positions which is marked by a double peak on the chromatograms (Treves 2010).

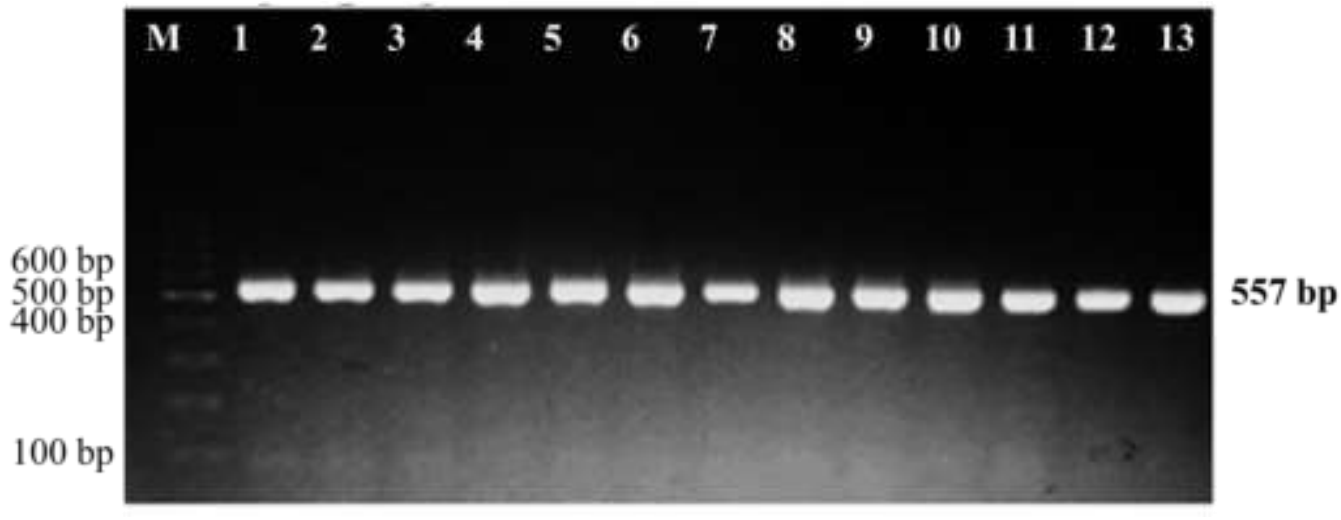

Figure 1. PCR amplification product of PRL gene (557 bp); M= DNA ladder 100 bp; 1-13 = IPB-D1 chicken samples

\section{Data analysis}

Genetic diversity analysis was performed by calculating genotype frequency and allele frequency. In addition, the chi-square value and heterozygosity values were also calculated. The formula for calculating allele frequencies and genotype frequencies according to Nei and Kumar (2000) is as follows.

$$
X_{i}=\frac{\left(2 N_{i i}+N_{i j}\right)}{(2 N)} ; \quad X_{j}=1-X_{i}
$$

Where, $\mathrm{Xi}=$ Frequency of the $\mathrm{i}^{\text {th }}$ allele; $\mathrm{Xj}=$ Frequency of the $\mathrm{j}^{\text {th }}$ allele; $\mathrm{Nii}=$ Number of samples with genotype ii; $\mathrm{Nij}=$ Number of samples with ij genotypes; and $\mathrm{N}=$ Number of samples.
Meanwhile, for the genotype frequency was calculated using the following formula.

$$
\begin{aligned}
& X_{i i}=\frac{N_{i i}}{N} \times 100 \% \quad X_{i j}=\frac{N_{i j}}{N} \times 100 \% \quad X_{j j} \\
& =\frac{\mathrm{N}_{\mathrm{jj}}}{\mathrm{N}} \times 100 \%
\end{aligned}
$$

Where, $\mathrm{Xii}=$ Frequency of the $\mathrm{ii}^{\text {th }}$ genotype; $\mathrm{Xij}=$ Frequency of the $\mathrm{j}^{\text {th }}$ genotype; and $\mathrm{Xjj}=$ Frequency of $\mathrm{ij}^{\text {th }}$ genotype.

Furthermore, genetic diversity was calculated using the frequency of observed heterozygosity (Ho) and expected heterozygosity $(\mathrm{He})$ was calculated using the Weir (1996) formulas as follows.

$$
H_{o}=\sum_{i \neq j} \frac{n_{i j}}{N} ; H_{e}=1-\sum_{i=j}^{q} X_{i}^{2}
$$


Where, Ho= heterozyegosity observations (population); $\mathrm{He}=$ value of expected heterozygosity; nij= number of heterozygous individuals; $\mathrm{N}=$ number of individuals observed; $\mathrm{Xi}=$ allele frequency; and $\mathrm{q}=$ number of alleles.

Genotype frequency deviations that arise from Hardy Weinberg's equilibrium were analyzed using the chi-square test $\left(\mathrm{x}^{2}\right)$ based on the Nei and Kumar (2000) formula as follows.

$$
\mathrm{X}^{2}=\sum_{\mathrm{i}=1}^{\mathrm{n}} \frac{(\mathrm{O}-\mathrm{E})^{2}}{\mathrm{E}}
$$

Where, $\mathrm{X}^{2}=$ chi-square test; $\mathrm{O}=$ Frequency observed sample genotypes; and $\mathrm{E}=$ frequency expected genotype.

\section{RESULTS AND DISCUSSION}

\section{Discovery single nucleotide polymorphisms of exon 5 prolactin gene}

The results of prolactin gene sequencing are shown in Figure 2. Sequencing results indicated the same mutation position based on Osman et al. (2018), Erehehuara (2003), and Li et al. (2013), i.e. g.8052T>C. Furthermore, 4 novel of mutation points were also found, namely g.7823A $>$ G, g.7835A $>$ G, g.7886T $>A$, and g.8069T $>$ C.

Single Nucleotide Polymorphism (SNP) is a form of differences in genetic material variation between two individuals in the form of a single nucleotide in a series of DNA nucleotide base sequences at specific locations in the genome (Murray et al. 2014). The mutation point positions on exon 5 found in this study are g.7823A $>\mathrm{G}$, g.7835A $>$ G, g.7886T $>$ A, g.8052T $>C$, and g.8069T $>C$ which all of them are classified as substitution mutations. In Figure 3, a partial sequence of prolactin gene mutations is described. Nucleotide base substitution mutations are divided into transition and transversion substitution mutations. The base mutations of $\quad$ g.7823A $>\mathrm{G}, \quad$ g.7835A $>\mathrm{G}, \quad$ g.8052T $>\mathrm{C}$, and g.8069T $>C$ classified as a transition mutation, which changes purine with other purine $(A>G)$ or pyrimidine with other pyrimidine $(C>T)$. Whereas transversion are purine substituted with pyrimidine bases or vice versa (Luo et al. 2016). Transition mutations are common, although most of them repaired by various proofreading function (Dubey 2014).

Adenine-Thymine in DNA conformation has two hydrogen bridges (Muladno 2010). Hydrogen bonds are non-covalent interactions that have small free energy of 2-6 $\mathrm{kj} \mathrm{mol}^{-1}$ in water, so that the strength of a weak bridge will be easily split and put back together (Ferst 2017). Changes in the structure of hydrogen bonds can affect DNA transcription and changes in the structure or shape of protein molecules produced. According to Luo et al. (2016), transversion mutations are more influential on changes in the structure and function of regulation of a gene than with transition mutations.

Each mutation that appears will affect 1 or more roles of the encoded protein. The role of proteins that may be affected by mutations is stability or folding protein, ligand binding protein, catalysis, regulation with allosteric and other mechanisms as well as posttranslational protein modification (Nagasundaram et al. 2015). Overall changes in amino acids from the prolactin gene mRNA sequence as a result of translation are presented in Table 1.

Table 1. Amino acids changes from the prolactin gene mRNA sequence as a result of translation

\begin{tabular}{ccll}
\hline \hline SNPs Position & \multicolumn{2}{c}{ Amino Acids Changes } \\
\hline g.7823 $\mathrm{A}>\mathrm{G}$ & Lysine $>$ & Lysine \\
g.7835A $>\mathrm{G}$ & Leucine $>$ & Leucine \\
g.7886T $>\mathrm{A}$ & Aspartate $>$ & Valine \\
g.8052T $>\mathrm{C}$ & Isoleucine $>$ & Isoleucine \\
g.8069T $>\mathrm{C}$ & Leucine $>$ & Serine \\
\hline
\end{tabular}

The g.7823A $>\mathrm{G}$ (Lys>Lys), g.7835A $>\mathrm{G}(\mathrm{Leu}>\mathrm{Leu})$ and g.8052T $>\mathrm{C}$ (Ile $>\mathrm{Ile}$ ) SNPs are synonymous mutations that do not change amino acids. Synonymous mutations can encode sequences with the same amino acid composition, but the structure and function of the protein can change by influencing the mechanism of RNA transcription, mRNA structure, and translational speed (Supek et al. 2014; (Sauna \& Kimchi-Sarfaty 2011).

The g.7886T $>$ A (Asp $>$ Val) and g.8069T $>C$ (Leu>Ser) SNPs are non-synonymous mutations that convert amino acids. The g.7886T $>$ A changes the aspartate amino acid to valine. The structure of these amino acids was changed where valine is one of three branched-chain amino acids (the others are leucine and isoleucine) that enhance energy, increase endurance, and aid in muscle tissue recovery and repair (NCBI 2020). This group also lowers elevated blood sugar levels and increases growth hormone production in chicken (Nascimento et al. 2016). The g.8096T $>C$ changes the leucine amino acid to serine. This amino acid changes involved in the functioning of RNA and DNA, in the muscle formation as well as in the maintenance of a proper immune system (NCBI 2020b).

Based on the mechanism of the prolactin gene action, mutations in DNA sequences can change the structure of the resulting protein so that it can affect the signaling pathway of the prolactin gene, especially in the process of attaching prolactin to its receptors. The prolactin pathway is initiated by attaching prolactin to its receptors. Prolactin receptors will induce signals and binds to the signal transduction also activates the protein transcription factor (Radhakrishnan et al. 2012).

Stat proteins (signal transducers and activators of transcription) will dissociate with their receptors and 


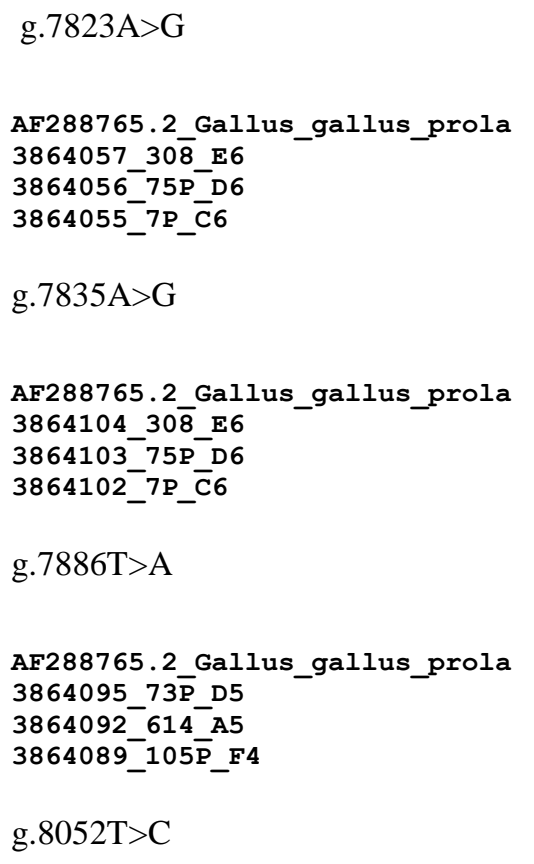

AF288765.2_Gallus_gallus_prola 3864055 7P_C6

$3864052-32 \overline{9}$ H5

3864051_109R_G5

g.8069T $>C$

AF288765.2 Gallus gallus prola $3864105 \quad 30 \overline{3}$ F6

$3864102-7 \mathrm{P} \overline{\mathrm{C}} 6$

3864099_329_H5

\begin{abstract}
7810
7820

7830

7840

7850

$\ldots|\ldots| \ldots|\ldots| \ldots|\ldots| \ldots|\ldots| \ldots|\ldots| \ldots|\ldots| \ldots|\ldots| \ldots \mid$ ACTTTACAAG CTGTACACTA CTAACTAGTG TTCCTCAAGG TCAATATTTC ACTTTACAAG CTGTACACTA CTGACTAGTG TTCCTCAAGg TCAATATTTC ACTTTACAAG CTGTACACTA CTGACTAGTG TTCCTCAAGG TCAATATTTC ACTTTACAAG CTGTACACTA CTGACTAGTG TTCCTCAAGG TCAATATTTC
\end{abstract}

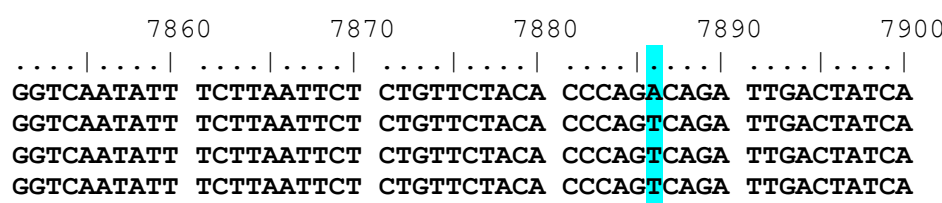

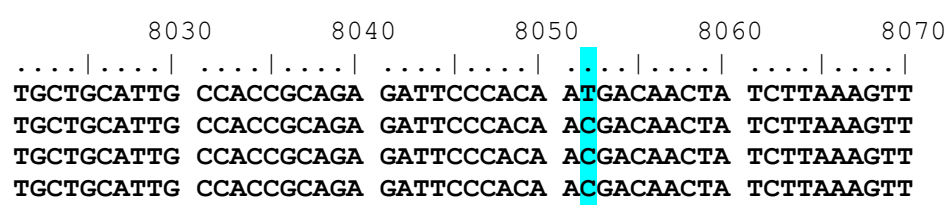

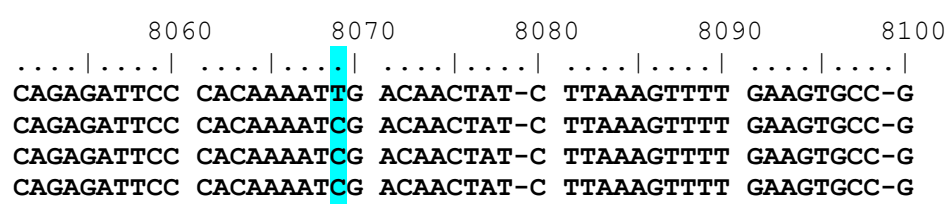

Figure 2. Alignmented of prolactin gene at exon 5 in IPB-D1 chicken showing 5 Single Nucleotide Polymorphisms (SNPs). Blue highlights show mutation point of each SNP

translocation will occur to the nucleus to bind to the target gene for the promoter prolactin. Attachment to the regulatory part of prolactin will regulate the active and inactive mechanism of the prolactin gene (Radhakrishnan et al. 2012). Thus, when a DNA sequence mutation occurs that changes the structure of the protein, it can cause inactivation of the prolactin gene

\section{Genotype frequency, allele frequency, and prolactin} gene heterozigosity

In this study, the chi-square analysis $\left(\chi^{2}\right)$ was conducted to determine whether the population is in Hardy-Weinberg equilibrium. In addition, this analysis was also carried out since in an experiment, often the results of crossing carried out offsprings that are not in accordance with Mendel's law. The population is mentioned to be in equilibrium if the calculated value of $\chi^{2}$ is smaller than $\chi^{2}$ table. A population that is in equilibrium means that the population has not yet experienced mutations, migration, directed marriages, selection, and large sample sizes (Castle 1903).

Heterozygosity is a parameter used to measure the level of genetic diversity in a population based on the allele frequency of each locus (Wang et al. 2015). Objective heterozygosity (Ho) is the average number of individuals with polymorphic locus based on observations, while expected heterozygosity $(\mathrm{He})$ is an estimate of genetic diversity based on the results of allele frequency calculations. The observed heterozygosity value is greater than the expected heterozygosity value. These findings indicate that the population is diverse. High genetic diversity has heterozygosity values of more than 0.50 (Karabağ et al. 2016). The results of genotype frequency, allele frequency, heterozygosity, and chi-square analysis $\left(\chi^{2}\right)$ of the prolactin gene at various locus are presented in Table 2 .

Genetic diversity in populations is illustrated by 3 diversity indices, namely the number (percentage) of polymorphic loci in the population, average. 


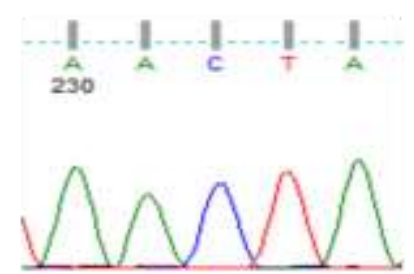

(a) No mutation

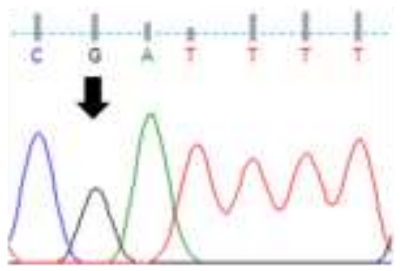

(d) g.7835A $>$ G (genotype GG)

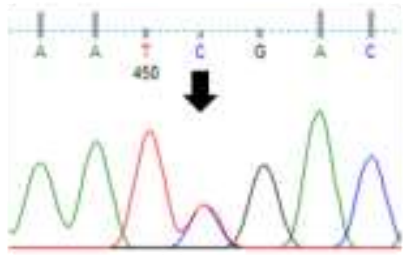

(g) g.8052 $\mathrm{T}>\mathrm{C}$ (genotype TC)

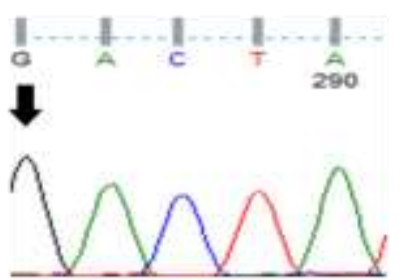

(b) g. $7823 \mathrm{~A}>\mathrm{G}$ (genotype GG)

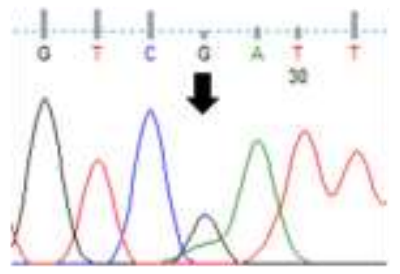

(e) g.7835A $>\mathrm{G}$ (genotype $\mathrm{AG}$ )

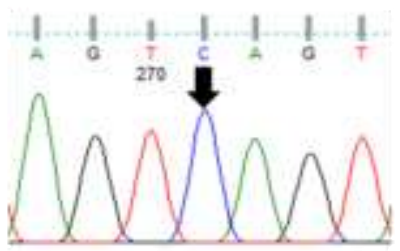

(h) g.8069T $>\mathrm{C}$ (genotype CC)

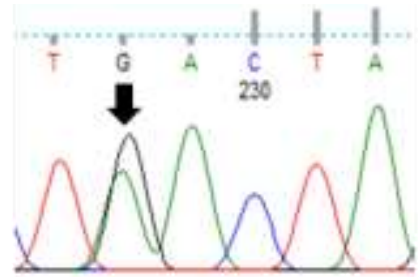

(c) g.7823A>G (genotype AG)

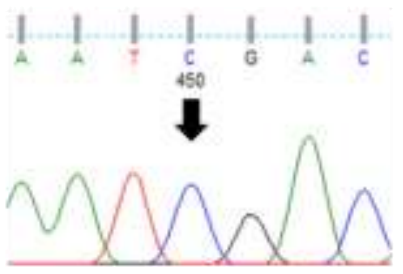

(f) g.8052T $>\mathrm{C}$ (genotype CC)

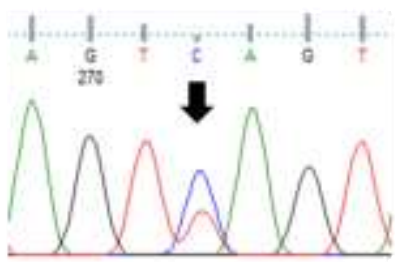

(i) g.8069T>C (genotype TC)

Figure 3. Partial sequencing maps of exon 5 prolactin gene showing transition mutations in IPB-D1 chicken. Arrows show mutation point.

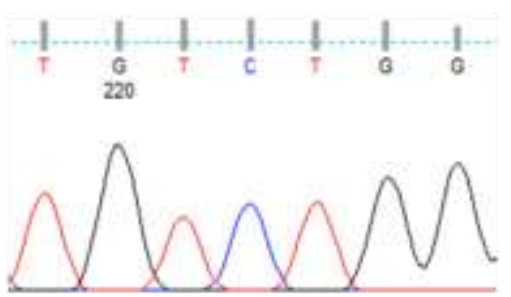

(a) No mutation

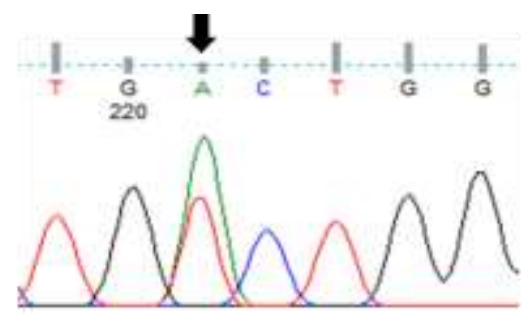

(b) g.7886 T/A (genotype TA

Figure 4. Partial sequencing maps of exon 5 prolactin gene showing transversion mutation in IPB-D1 chicken. Arrow shows mutation point.

Table 2. Genotype frequency, allele frequency, heterozygosity, and chi-square test $\left(\chi^{2}\right)$ prolactin gene values at various locus in IPB-D1 chicken

\begin{tabular}{|c|c|c|c|c|c|c|c|c|c|}
\hline SNP & $\mathrm{N}$ & & otype freque & & Allele & quency & $\chi^{2}$ & $\mathrm{H}_{\mathrm{o}}$ & $\mathrm{H}_{\mathrm{e}}$ \\
\hline $\begin{array}{l}\text { g. } 7823 \\
A>G\end{array}$ & 46 & $\begin{array}{l}\text { AA } \\
0.50(23)\end{array}$ & $\begin{array}{c}\mathrm{AG} \\
0.37(17)\end{array}$ & $\begin{array}{c}\mathrm{GG} \\
0.13(6)\end{array}$ & $\begin{array}{c}\mathrm{A} \\
0.68\end{array}$ & $\begin{array}{c}\mathrm{G} \\
0.32\end{array}$ & $0.95^{\mathrm{ns}}$ & 0.43 & 0.37 \\
\hline $\begin{array}{l}\text { g. } 7835 \\
A>G\end{array}$ & 46 & $\begin{array}{l}\text { AA } \\
0.22(10)\end{array}$ & $\begin{array}{c}\mathrm{AG} \\
0.57(26)\end{array}$ & $\begin{array}{c}\text { GG } \\
0.22(10)\end{array}$ & $\begin{array}{c}\mathrm{A} \\
0.50\end{array}$ & $\begin{array}{c}\mathrm{G} \\
0.50\end{array}$ & $0.78^{\text {ns }}$ & 0.57 & 0.50 \\
\hline $\begin{array}{l}\text { g. } 7886 \\
\text { T>A }\end{array}$ & 46 & $\begin{array}{l}\text { TT } \\
0.91(42)\end{array}$ & $\begin{array}{c}\text { TA } \\
0.09(4)\end{array}$ & $\begin{array}{c}\text { AA } \\
0.00(0)\end{array}$ & $\begin{array}{c}\mathrm{T} \\
0.96\end{array}$ & $\begin{array}{c}\text { A } \\
0.04\end{array}$ & $0.14^{\mathrm{ns}}$ & 0.09 & 0.08 \\
\hline $\begin{array}{l}\text { g. } 8052 \\
\text { T>C }\end{array}$ & 46 & $\begin{array}{l}\text { TT } \\
0.69(32)\end{array}$ & $\begin{array}{c}\mathrm{TC} \\
0.22(10)\end{array}$ & $\begin{array}{c}\text { CC } \\
0.09(4)\end{array}$ & $\begin{array}{c}\mathrm{T} \\
0.80\end{array}$ & $\begin{array}{c}\mathrm{C} \\
0.20\end{array}$ & $4.27^{*}$ & 0.22 & 0.31 \\
\hline $\begin{array}{l}\text { g. } 8069 \\
\text { T>C }\end{array}$ & 46 & $\begin{array}{l}\text { TT } \\
0.26(12)\end{array}$ & $\begin{array}{l}\text { TC } \\
0.57(26)\end{array}$ & $\begin{array}{l}\mathrm{CC} \\
0.17(8)\end{array}$ & $\begin{array}{l}\mathrm{T} \\
0.46\end{array}$ & $\begin{array}{l}\mathrm{C} \\
0.54\end{array}$ & $0.89^{\mathrm{ns}}$ & 0.57 & 0.50 \\
\hline
\end{tabular}

$\mathrm{N}=$ total sample; $(\mathrm{n})=$ number of samples on the genotype. ${ }^{*}=$ significantly different at $\mathrm{P}<0.05\left(\mathrm{x}_{0.05}^{2}=3.84\right), \mathrm{ns}=$ non significant 
heterozygosity at Hardy-Weinberg equilibrium, and allele frequencies (Nei \& Kumar 2000). Allele frequency is a measure of the relative frequency of an allele in a population that shows genetic diversity. An allele can be said to be polymorphic if it has the same frequency or less than 0.99 (Hartl \& Clark 2000).

The results of the study found five points mutation on exon 5: i.e g.7823A $>$ G, g.7835A $>$ G, g.7886T $>A$, g. $8052 \mathrm{~T}>\mathrm{C}$, and g.8069T $>\mathrm{C}$. The g.7823A $>\mathrm{G}$ and g.7835A > G SNPs produced 3 genotypes: AA, AG, and GG. The g.7823A $>\mathrm{G}$ had a higher AA (50.00\%) genotype frequency compared to the AG $(36.96 \%)$ and GG (13.04\%) (Table 2). The high frequency of the AA genotype resulted in a higher range of the $\mathrm{A}$ allele frequency (0.68) compared to the $G$ allele frequency (0.32) which indicated that the locus was polymorphic. Allele frequency is a measure of the relative frequency of an allele in a population that shows genetic diversity. An allele is classified as polymorphic if it has a frequency equal to or less than 0.99 (Hartl \& Clark 2000). The results of the Hardy-Weinberg equilibrium test showed that the results were not significantly different $(\mathrm{P}>0.05)$ or were in the Hardy-Weinberg equilibrium. This result is in line with the results of the heterozygosity value in IPB-D1 chickens which showed that the observed heterozygosity value (Ho) was higher than the value of expected heterozygosity $(\mathrm{He})$, which means that the population that has mutations at the locus g.7823 $\mathrm{A}>\mathrm{G}$ varied.

The g.7835A $>\mathrm{G}$ locus also showed polymorphic properties in IPB-D1 chickens. The frequency of the AG genotype $(57.00 \%)$ was higher than the AA $(22.00 \%)$ and GG (22.00\%) genotypes (Table 2), resulting in balanced $A(0.50)$ and $G(0.50)$ allele frequency. The results of the $\mathrm{x}^{2}$ were in the HardyWeinberg equilibrium $(\mathrm{P}>0.05)$ which indicated that the observed heterozygosity value was higher than the expected heterozygosity value, which meant that the population that had mutations at locus g.7835A $>\mathrm{G}$ varied.

SNP at locus g.7886T $>$ A was found only 2 genotypes, namely TT $(91.30 \%)$ and TA $(8.70 \%)$. The high frequency of the TT genotype resulted in a higher range of the T allele (0.96) than the A allele (0.04), and the frequency magnitudes of these two alleles showed polymorphic. The genotype frequency of SNP locus g.7886T $>$ A based on the chi-square value $\left(\chi^{2}\right)$, the IPBD1 chickens were in Hardy-Weinberg equilibrium $(\mathrm{P}>0.05)$. This is reinforced by the results of the calculation of the heterozygosity value obtained in IPBD1 chickens, that the observed heterozygosity value is greater than the expected heterozygosity value which means that the population at the locus is polymorphic.

SNP at locus g.8052T $>\mathrm{C}$ found 3 kinds of genotypes: TT $(69.57 \%)$, TC $(21.74 \%)$, and CC $(8.70 \%)$ (Table 2$)$. The high frequency of TT genotypes resulted in higher $\mathrm{T}$ allele (0.80) compared to $\mathrm{C}$ allele (0.20) so that the g.8052 locus was also polymorphic in IPB-D1 chickens. The results of the Hardy-Weinberg balance test with the chi square test $\left(\chi^{2}\right)$ indicate that they are in Hardy-Weinberg equilibrium $(\mathrm{P}>0.05)$. The g.8069T $>\mathrm{C}$ locus also produced 3 genotypes: TT (26.09\%), TC (56.52\%), and CC (17.39\%) (Table 2). The frequency of the $\mathrm{C}$ allele $(0.54)$ is greater than the $\mathrm{T}$ allele (0.46) and shows the polymorphism of the prolactin gene in IPB-D1 chickens. Allele frequencies in the five SNPs identified have a value $\leq 0.99$. Therefore it can be concluded that the prolactin gene in chicken IPB-D1 is polymorphic. An allele is classified as polymorphic if it has an allele frequency $\leq 0.99$ (Hartl \& Clark 2000).

In this current study, based on allele frequencies, the PIC values calculated the result ranged from 0.08 (g.7886) to 0.50 (g.7835 and g.8069) and the average PIC values were calculated from overall locus as 0.37 . DNA markers showed an average $0.25<$ PIC value < 0.50 , which confirms that the marker is reasonably informative (Botstein et al. 1980). The Hardy-Weinberg equilibrium test results, which have been carried out, are known to be in Hardy-Weinberg equilibrium (P) 0.05) which means that the observed heterozygosity values are higher than the expected heterozygosity values. From these findings, it can be said that the population that has mutations at the locus is diverse. This is possible because of several factors, including the lack of optimal selection efforts for chickens from IPBD1. Castle (1903) states that a large population will not change from one generation to another if there is no selection, migration, mutation, and genetic drift.

The SNP of the exon 5 of the prolactin gene has actually been previously studied and found SNP at position g.8052T $>\mathrm{C}$ in local Chinese chickens, namely Qinyuan Patridge chickens and in recessive white chickens (Erehehuara 2003; Li et al. 2013). In addition, non-synonymous SNP position g.7921C>T was found which changed the amino acid Ser into Pro and SNP synonymous at position $\mathrm{g} .8187 \mathrm{C}>\mathrm{T}$ in the $\mathrm{F} 15$ hubbard chicken (Osman et al. 2018). The results of SNP identification at $\mathrm{g} .8052 \mathrm{~T}>\mathrm{C}$ in this study are in accordance with the SNP findings of Li et al. (2013) and Erehehuara (2003). Li et al. (2013) showed in the results of his study that the position of SNP g.8052T >C was significantly related to the first age of the chicken laying eggs and the amount of egg production at the age of the first 300 days laying eggs. The g.8052T $>$ C SNP located in the coding region of the gene, but does not change the amino acid sequence, although the egg production traits between two chicken breeds were significantly different, the allele frequencies of the two sites in both breeds were close and only significant genotypic effects existed. The association analysis suggested that there were significant associations 
between T8052C and G8113C genotypes of PRL gene and the egg production traits of AFE and EN 300. Moreover, the breed effect and the interaction effect between breeds and genotypes are not significant, and therefore, it was concluded that there may be a relationship between these two SNP sites and egg production traits in chickens. In this study, the $\mathrm{H} 2 \mathrm{H} 3$ diplotype was also found to be associated with more egg production traits than other diplotypes $(\mathrm{H} 2 \mathrm{H} 2$, $\mathrm{H} 2 \mathrm{H} 4$ and $\mathrm{H} 3 \mathrm{H} 3$ ), indicating that $\mathrm{H} 2 \mathrm{H} 3$ diplotype may be the most advantageous haplotypes for egg production. Erehehuara (2003) also mentioned that SNP g.8052T $>C$ and g.8113G $>C$ greatly influenced egg production in white leghorn and brown hy-line chickens, that the frequency of A1A1 genotype, was 1.0 and 0.84 in white leghorn and brown hy-line egg layers, respectively.

\section{CONCLUSION}

Five SNPs have been found in the exon 5 of prolactin gene fragments in IPB-D1 chicken. The five SNPs including g.7823A $>$ G, g.7835A $>$ G, g.7886T $>A$, g.8052T $>C$, and g.8069T $>C$. The g.7823A $>$ G, g.7835A $>\mathrm{G}$, and $\mathrm{g} .8052 \mathrm{~T}>\mathrm{C}$ are synonymous mutations, whereas g.7886T $>A$ and g.8069T $>C$ are non-synonymous mutation which alters change amino acids. Both g.7886T $>$ A and g.8069T $>C$ can be used as a candidate of marker-assisted selection for egg production in IPB-D1 chicken. Further studies are needed to confirm this hypothesis.

\section{ACKNOWLEDGEMENT}

We thank to Ministry of Research, Technology and Higher Education (Indonesia), which has financed this research through the collaboration of World Class Research, with the contract number: 121/SPH/LT/DRPM/2019.

\section{REFERENCES}

Alzohairy AM. 2011. BioEdit: An important software for molecular biology. GERF Bull Biosci. 2:60-61.

Botstein D, White R, Skolnick M, Davis R. 1980. Construction of a genetic linkage map in man using restriction fragment length polymorphisms. Am J Hum Genet. 32:314-31.

Castle WE. 1903. The Laws of Heredity of Galton and Mendel, and Some Laws Governing Race Improvement by Selection. Proc Am Acad Arts Sci. 39:223.

Cholifah U. 2018. Produktivitas ayam persilangan pelung sentul kampung ras pedaging (PSKM) G3 pada umur 12 minggu sampai produksi telur. [Bogor(Indones)]:IPB University.

[DJPKH] Direktorat Jenderal Peternakan dan Kesehatan Hewan. 2019. Statistik Peternakan dan Kesehatan Hewan 2019. Jakarta (Indones): Direktorat Jenderal Peternakan dan Kesehatan Hewan-Kementerian Pertanian RI.

Dubey R. 2014. Advanced Biotechnology. New Delhi (IN): S. Chand.

Erehehuara. 2003. Studies on the SNP of the chicken's prolactingene. [Wuhan (China)]: Huazhong Agricultural University.

Ferst A. 2017. Structure and Mechanism in Protein Science: A Guide to Enzyme Catalysis and Protein Folding. New Jersey (US): World Scientific.

Habiburahman R, Darwati S, Sumantri C, Rukmiasih. 2020. Produksi Telur dan kualitas telur ayam IPB D-1 G7 serta pendugaan nilai ripitabilitasny. J Ilmu Produksi dan Teknol Has Peternak. 8:97-101.

Hartl D, Clark A. 2000. Principles of Population Genetics. 3rd ed. Massachusetts (USA): Sinaeus Assosiatess Inc.

Hidayat C, Asmarasari SA. 2015. Native chicken production in Indonesia: a review. J Peternak Indones. 17:1-11.

Karabağ K, Balcıŏglu MS, Karlı T, Alkan S. 2016. Determination of genetic diversity using 15 simple sequence repeats markers in long term selected Japanese quail lines. Asian-Australasian J Anim Sci. 29:16961701.

Kumar S, Stecher G, Li M, Knyaz C, Tamura K. 2018. MEGA X: molecular evolutionary genetics analysis across computing platforms. Battistuzzi FU, editor. Mol Biol Evol. 35:1547-1549.

Li H-F, Shu J-T, Du Y-F, Shan Y-J, Chen K-W, Zhang X-Y, Han W, Xu W-J. 2013. Analysis of the genetic effects of prolactin gene polymorphisms on chicken egg production. Mol Biol Rep. 40:289-294.

Luo G-H, Li X-H, Han Z-J, Zhang Z-C, Yang Q, Guo H-F, Fang J-C. 2016. Transition and transversion mutations are biased towards $\mathrm{gc}$ in transposons of chilo suppressalis (Lepidoptera: Pyralidae). Genes (Basel). $7: 72$

Muladno. 2010. Teknologi Rekayasa Genetika. 2nd ed. Bogor (Indones): IPB Press.

Murray R, Bender D, Botham K, Jennely P, Rodwell V, Weil P. 2014. Biokimia Harper. 29th ed. Jakarta (Indones): EGC.

Nagasundaram N, Zhu H, Liu J, V K, C GPD, Chakraborty C, Chen L. 2015. Analysing the Effect of Mutation on Protein Function and Discovering Potential Inhibitors of CDK4: Molecular Modelling and Dynamics Studies. Salsbury F, editor. PLoS One. 10:e0133969.

Nascimento G, Murakami A, Ospina-Rojas I, Diaz-Vargas M, Picoli K, Garcia R. 2016. Digestible valine requirements 
in low-protein diets for broilers chicks. Rev Bras Ciência Avícola. 18:381-386.

[NCBI] National Center for Biotechnology Information. 2020a. PubChem Compound Summary for CID 6287, Valine. [accessed September 28 2020 ] https://pubchem.ncbi.nlm.nih.gov/compound/Serine

[NCBI] National Center for Biotechnology Information. 2020b. PubChem Compound Summary for CID 5951, Serine. [accessed September 29, 2020]. https://pubchem.ncbi.nlm.nih.gov/compound/Serine

Nei M, Kumar S. 2000. Molecular Evolution and Phylogenetics. New York (US): Oxford Univ Pr.

Osman MMM, Hemeda SA, Hassanin AAI, Husseiny WA. 2018. Polymorphism of prolactin gene and its association with egg production trait in four commercial chicken lines. J Hell Vet Med Soc. 68:391-404.

Plant T, Zeleznik Z. 2014. Knobil and Neill's Physiology of Reproduction. London (UK): Academic Press.

Radhakrishnan A, Raju R, Tuladhar N, Subbannayya T, Thomas JK, Goel R, Telikicherla D, Palapetta SM, Rahiman BA, Venkatesh DD, et al. 2012. A pathway map of prolactin signaling. J Cell Commun Signal. 6:169-173

Sambrook J, Russell DW. 2001. Molecular cloning: a laboratory manual. 3rd ed. New York (US): Cold Spring Laboratory Press.

Sartika T. 2005. Peningkatan mutu bibit ayam kampung melalui seleksi dan pengkajian penggunaan penanda genetik promoter prolaktin dalam MAS/Market Assisted Selection untuk mempercepat proses seleksi. [Bogor (Indones)]: Institut Pertanian Bogor.

Sauna ZE, Kimchi-Sarfaty C. 2011. Understanding the contribution of synonymous mutations to human disease. Nat Rev Genet. 12:683-691.
Sharp PJ, Scanes CG, Williams JB, Harvey S, Chadwick A. 1979. Variation in concentrations of prolactin, luteinizing hormone, growth hormone and progesteron in the plasma of broody Bantams (Gallus domesticus). J Endocrinol. 80:51-57.

Sherwood L, Klandorf H, Yancey P. 2005. Animal Physiology: From Genes to Organisms. Boston (USA): Cengage Learning.

Sinurat A, Santoso, Juarini E, Sumanto, Murtisari T, Wibowo B. 1992. Peningkatan produktivitas ayam buras melalui pendekatan sistem usaha tani pada peternak kecil. Ilmu dan Peternak. 5:73-77.

Sumantri C, Darwati S. 2017. Perkembangan terkini riset ayam unggul IPB-D1. In: Pros Semin Nas Ind Peternak. Bogor (Indones): Fakultas Peternakan, Institut Pertanian Bogor; p. 3-7.

Supek F, Miñana B, Valcárcel J, Gabaldón T, Lehner B. 2014. Synonymous mutations frequently act as driver mutations in human cancers. Cell. 156:1324-1335.

Treves DS. 2010. Review of three DNA analysis applications for use in the microbiology or genetics classroom. J Microbiol Biol Educ. 11:186-187.

Wang J, Raskin L, Samuels DC, Shyr Y, Guo Y. 2015. Genome measures used for quality control are dependent on gene function and ancestry. Bioinformatics. 31:318-323.

Weir BS. 1996. Genetic data analysis II: methods for discrete population genetic data. Sunderland (UK): Sinauer Associates Inc.

Ye J, Coulouris G, Zaretskaya I, Cutcutache I, Rozen S, Madden TL. 2012. Primer-BLAST: A tool to design target-specific primers for polymerase chain reaction. BMC Bioinformatics. 13:134. 